Literatura y Lingüística $\mathrm{N}^{\circ} 26$

ISSN 0716-5811 / pp. 167-179

\title{
Inversion of biblical symbols in The Grapes of Wrath $^{*}$
}

\author{
Miriam Pérez Veneros**
}

\begin{abstract}
Although it is agreed that Steinbeck's The Grapes of Wrath (1939) is full of allusions and symbols connected to the Bible, no consensus has been reached yet about their nature. In this article an analysis is described which aims at demonstrating that the allusions and symbols found are better interpreted as inversions of the traditional biblical symbols, in such a way that the novel can be considered a new 'bible for the people'.
\end{abstract}

Keywords: biblical symbolism, biblical inversions, 'bible for the people'

\section{Inversión de los símbolos bíblicos en Las Uvas de la Ira}

\section{Resumen}

Si bien los expertos están de acuerdo en que Las Uvas de la Ira (1939) de Steinbeck está cargada de alusiones y símbolos, no existe aún un consenso sobre la naturaleza de los mismos. En este artículo, se presenta un análisis que busca demostrar que la alusiones y símbolos de la obra son interpretados de forma más coherente como inversiones de los símbolos bíblicos tradicionales, de tal modo que la novela puede ser considerada un nueva 'biblia para el pueblo'.

Palabras clave: simbología bíblica, inversiones bíblicas, 'biblia para el pueblo'

Recibido: 12-03-2012 Aceptado: 11-08-2012

* Este artículo es parte de la investigación del Programa de Doctorado en estudios ingleses avanzados que sigue su autora en la Universidad de Salamanca.

** Doctorandaen el programade DoctoradoenEstudios Ingleses Avanzados: Lenguasy Culturasen Contacto.Universidad de Salamanca, España. Departamento de Filología Inglesa. mpveneros@usal.es 
Welcome to the new world order Families sleepin' in their cars in the Southwest No home, no job, no peace, no rest. Bruce Springsteen, from the song "The Ghost of Tom Joad"

\section{Introduction}

Just think about a whole landscape covered in dust and people trying to cope with this brownish and dry mist. This is exactly the situation that millions of Americans had to go through between the years 1930 and 1936. The 'Dust Bowl', as this phenomenon is widely known, was a period of tremendous dust storms causing agricultural and ecological damage in the southern plains. Since there were terrible droughts, the soil dried and turned into dust. When the wind blew, this dust dispersed everywhere. Many farmlands became useless and whole families had to abandon their homes in search for a better life. They mainly travelled to California and other states "where the land was more productive and jobs appeared to be more available" (Marshall, 2009, 27), only to find living conditions no better than the ones they had left behind. This is the situation that is treated in the book that is under analysis in this paper: The Grapes of Wrath, by John Steinbeck.

This novel is one of the greatest ones written in the 20th century in America. It faithfully addresses the suffering and grievances of American people during the Dust Bowl. Many aspects of the book have been under discussion by critics. Some of them have studied this novel because of its political traits and reception (Dunbar, 20003; Staples Shockley, 1944), while others have focused their attention on the characters and their different roles (Motley, 1982; Cruz, 2007). Some authors such as Marshall have studied the different landscapes that appear in the novel as a way of showing people's feelings and emotions (Marshall, 2009). However, one of the fields that have been less explored when dealing with Steinbeck's novel is the use of biblical symbolism and its possible role and function in the novel. Controversy has arisen with regard to this aspect, since there are two main stances that both critics and writers take. Some authors (e.g. Chametzky, 1965; Lisca 1957, 1972; Shockley, 1956) argue that The Grapes of Wrath is a revision of the traditional Bible, using the same symbolism and simply substituting the protagonists of the Bible and their situations for the members of the Joad family and their lives. As Shockley asserts, the whole book is elaborated through

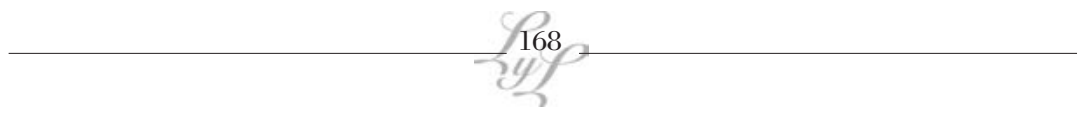


a sequence of Christian symbols and the final meaning of it is revealed when the significance of the symbols has been wholly apprehended (Shockley, 1956, 89). Nevertheless, other critics have rejected this idea, defending that the novel presents biblical inversion of those symbols, assigning a completely different function to the book, and giving interpretations other than biblical (Carlson, 1958; Crockett, 1962; Railton, 1990; Rombold, 1987). With this new vision, I want to suggest that the novel becomes something more than a Bible full of religious symbols. In Carlson's words (Carlson, 1958, 172), "the main theme reflects both a foreground of natural symbolism and the author's philosophic perspective in scientific humanism." This interpretation has been less considered and analysed by critics and there are still some aspects of it that remain unexplored.

For all these reasons, this paper intends to provide a revision of some of the symbols used in the book, considering and analysing them as oppositions or inversions of the symbols which are used in the traditional Bible. The study particularly centres on three main aspects of the book. First, a revision and analysis will be made of some of the main characters who appear in the book. Then, I will focus on the journey to the land of California the Joads embark on and how it could be seen as an inversion of the journey of the Israelites to the land of Canaan. Finally, the last part of the paper will deal with the meaning implied in the symbol of the final flood which devastates the place where the Joads live. In so doing, it is expected that this paper sheds some light on the new meaning which is given to the book. It is not seen as a traditional Bible, but as a book for the people where the tragic and difficult situation of many Americans in the 1930s can be reflected and thus much better understood.

\section{Analysis of the characters}

The characters that appear in Steinbeck's novel are the new saviours for the people if they are compared to the characters in the Bible. Tom Joad stands as the greatest representation of the love for man, nature and justice. Some authors have agreed in assigning him the role of Christ (Rombold, 1987, 158), but he does not portray this character any more. The love and empathy he feels for humanity are the emotions which lead him to act as he does at the end of the novel. Just as Railton (1990, 37) argues, "Tom finds a freedom and a meaning that living for himself or for his family could never have bestowed upon his acts." He decides to abandon his family at the end of the book because he has understood 
that his mission is to convince people of remaining together and forming a great community as the only way of surviving in that hostile land they inhabit. He knows that this new gospel of human cooperation has to be transmitted to all the people. Thus, he decides to take the role of messenger of that revelation because he is aware of the fact that people need to hear some encouraging words to overcome all the grievances and suffering in the land of California. This may be interpreted as a sacrificial act, since Tom abandons his former life to become the messenger of men. Nevertheless, Tom undertakes this venture because he is eager to transmit to everybody that only by cooperation, joint efforts and mutual aid could people achieve their goals and be free. Contrary to the figure of Christ, if Tom died, he would not help anybody. His comrades will receive some help and they will be infected by his love for man and justice only if he is alive to tell them so. He becomes a mass leader, a kind of lighthouse for the people who inhabit that hostile land. As Railton defends, "Wherever the people are, that's Tom new home" (Railton, 1990, 37). Now, his new place and home is with the people and their suffering and problems, as can be seen in the book: "Then it don' matter. Then I'll be all aroun' in the dark. I'll be ever'where-wherever you look"' (Steinbeck, 2000, 439). Tom is going to inhabit all the places where there is injustice as a living soul that takes care for all humanity, transforming the individual "I" into the collective "we".

Tightly linked with this idea of the people standing together and forming a great family is Ma Joad. As Tom portrays the role of the messenger of all humanity, Ma Joad becomes the messenger, saviour and pillar of her family. In fact, "she acts as the cohesive force that keeps her brood intact" (Bluestone, 1972, 109). She has sometimes been compared to the character of Rachel in the Bible (Rombold, 1987, 161), the one who spoke to God for Him to forgive the Jews and send them back to their lands. It is true that Ma does everything she can to help her people and to keep them together, but it is also true that she does not speak to God and she does not receive any help from Him. Her own strength and willingness help her keep the members of her family together and transmit them a sense of hope and positivism. She does not speak to God, she speaks to her family and she embodies the symbol of total regeneration for them (Crockett, 1962, 198). Similar to her son Tom, she is also guided by her love for her people, especially for her family. She has understood that worse than not finding a job or not having anything to eat is the break of bonds among the members of the family. She thinks that the only way of achieving some goals is to maintain unity and boundaries.

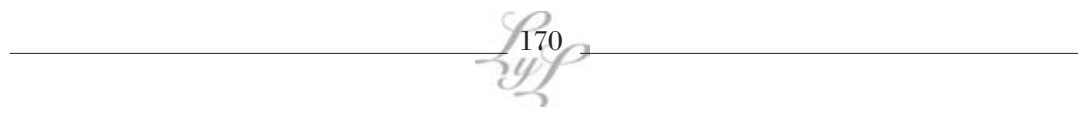


It could be suggested that the motto which guides her acts is "United we stand" and that it is the only possible way of surviving in that hostile land which is California: "Easy,' she said. 'You got to have patience. Why, Tom-us people will go on livin' when all them people is gone"' (Steinbeck, 2000, 293). Besides, she represents all women's strength and courage, which is why she has more power over the family than $\mathrm{Pa}$ does. She defines it very well when she tells him: "It ain't, Pa. An' that's one more thing a woman knows. I noticed that. Man, he lives in jerks. Woman, it's all one flow, like a stream, little eddies, little waterfalls, but the river, it goes right on'" (Steinbeck, 2000, 443). As I have stated previously, both Tom and Ma Joad could be considered in a similar way, with the difference that Tom is the messenger and force of the people and $\mathrm{Ma}$ of her family. In the Bible, Christ is the saviour of humanity. In this novel, Ma and Tom are also able to save the human being. Yet, this is not achieved through the guidance of God, but through their love for nature, people and social justice.

Two of the most powerful characters in their biblical inverted roles are Uncle John and baby Joad, his stillborn nephew. The baby stands for the new Moses, despite the fact that his role is contrary to the one Moses played. If the story of this biblical character is brought into the discussion, it tells the reader that Moses was saved from the waters when he was a baby and, as an adult, he released his people from Egyptian slavery, leading them to the Promised Land. In the case of baby Joad, he is a stillborn child who is sent by his uncle John down the waters as a reminder of the misery his people are suffering. However, unlike the biblical character, he is not able to save his people; he is only there as a reminder and as a symbol of all the grievances imposed upon the Okies who arrived in California with the hope of getting a second chance to start a new life. As Rombold affirms, Uncle John inverts the story of Moses when he sends his dead nephew down the water. Moses was alive, while this baby is dead and he is not rescued from the waters (Rombold, $1987,161)$. The baby cannot do anything to save his people, except for serving as a warning and as a signal of their suffering. Besides, this baby does not play the role of the leader who guides his comrades to a new land full of richness and opportunities. Nobody is going to guide the people to the new land, because they are already in that land and they have to learn how to survive in a hostile territory which does not belong to them. Moses freed his people from the Egyptian Pharaoh and his boundaries. Baby Joad does not free anybody. Uncle John only assigns him the role of saviour, as he embodies the suffering of the immigrants 
in the land of California: "He said fiercely, 'Go down an' tell 'em. Go down in the street an' rot an' tell 'em that way. That's the way you can talk. Go on down now, an' lay in the street. Maybe they'll know then'" (Steinbeck, 2000, 468). The stillborn baby could be considered a text made up of died flesh and blood that talks about grievances, sorrow, hunger, suffering and misery. It reflects the critical situation of the immigrants in California. Furthermore, it also acts as a book that informs the Californians who "read" it that they are doing things wrong, that they are treating people as merchandise and that they are taking advantage of their poverty, necessity and desperation.

Finally, when dealing with the different characters in the novel, it is important to analyse the role of Rose of Sharon, baby Joad's mother. Rose of Sharon becomes Mother Nature, the one who nurtures humanity and she does it out of the love and compassion she feels for all the people. Some critics such as Lisca and Chametzky have agreed in comparing Rose of Sharon to the Rose of Sharon in the Bible. As it is argued, "Rose of Sharon's giving of new life to the old man is another reference to the orthodox interpretation of Canticles 'I am the Rose of Sharon, and the lily of the valleys (Song of Solomon 2:1)'” (Lisca, 1972, 95). In addition, she has also been compared to Christ and his sacrificial act of death (Chametzky, 1965, 35). However, the Rose of Sharon in the book is not like the idealized Rose of Sharon in the Bible. The girl in the novel is weak and spoiled and does not do anything throughout the journey except for grumbling. It is only at the end of the novel, when she feeds a starving man with the milk of her breasts, that she understands and discovers her love for mankind and the necessity to help those who are in great need. Furthermore, Rose of Sharon does not die for the benefit of humanity; rather, she helps humanity survive through the feeding of a man. This man stands as a metonymy of all the people who are dying of hunger in California and Rose stands for the universal mother who is going to feed her children. Rose of Sharon is disappointed because she has lost her child and the promise of being a mother has not been fulfilled. That is why when she encounters the dying man, she understands that she can act as a mother to him, because "the prime function of life is to nourish life" (Carlson, 1958, 174). Rose of Sharon is the symbol of the new life and the new coming era, a place where a new community can be built and in which all the problems are shared and tried to be solved out of cooperation and comradeship. In the character of this girl, the idea of the people standing together and forming a great family can be recognized again. This is the only way of surviving in the new but hostile

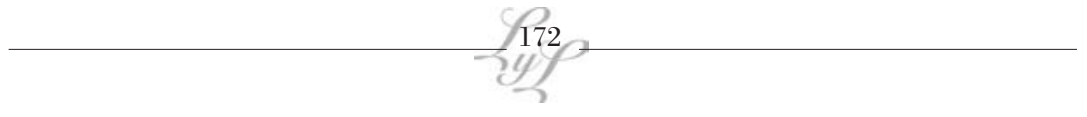


land. The act in which Rose of Sharon gives her milk to the man can be understood as an act of profound compassion and sympathy for other people's problems and suffering: "Rose of Sharon loosened one side of the blanket and bared her breast. 'You got to,' she said. She squirmed closer and pulled his head close. 'There!' she said. 'There"' (Steinbeck, 2000, 476). In this act underlies the very idea of collectiveness as opposed to individuality and egoism. Besides, the most important thing is that Rose of Sharon does not take this decision because of her faith or her religion. She simply loves humanity and she wants all human beings to survive. It has been claimed that Rose of Sharon "es la madre de la humanidad que alimenta, no al hijo pródigo de Dios, sino a un simple campesino" (Quint, 2003, n.p.). She is portrayed as Mother Nature, the new mother of humanity and she does it out of love, not out of religion. As it was pointed out at the beginning of the paper, this is also another example which demonstrates that the book, rather than being a new bible full of religious symbols, is a book for humanity where the basics of human behaviour, ethics and values lie.

\section{The journey to the "Promised Land"}

When dealing with the journey the Joads embark on, it could be stated that it is a clear inversion of the journey of the Israelites to the Promised Land. The Joads do not feed from the manna of Heaven, but rather from what they can afford with almost no money. This topic of the travelling as the route the Israelites took is a recurrent one for most critics who talk about the appearance of biblical symbols in the novel. Lisca argues that "The Grapes of Wrath" is divided into thirty consecutive chapters and the novel is made up of three major parts: the drought (Egypt), the journey (Exodus) and California (the land of Canaan)" (Lisca, 1972, 93-94). However, what these authors do not say is that we can find an inversion of the supposedly Promised Land at the end of the journey. The Joads thought they were going to find a place full of opportunities, but the only thing they find is rejection, hatred and misery. God had made the people in the Exodus a promise that He was going to guide them from the land of Egypt to a new land full of milk and honey, where all their grievances would end. Nevertheless, what the Joads find is that Canaan, that mythical and promising land "is destroyed by the brutal reality of migrant life in California and the past they left at the other end of Route 66 appeals to them as the paradise they have been driven from" (Railton, 1990, 31). California is not a place better than the one 
they left behind. In fact, it is even worse. In Oklahoma, the Joads had at least a roof over their heads and they felt at home. In California, they have nothing; they have to survive by working in very bad and poor conditions for a negligible salary. The Israelites, after a journey in which they were guided and helped by God, arrived at a land full of richness and manna. Ostensibly, this same land is the dream the Joads expect to find in California: green valleys, white houses, fruit and jobs everywhere. In fact, they find a place of misery and poverty, at least for them. California is just as they imagined it, except for the fact that it does not belong to them. It belongs to Californians and immigrants are rejected because they come from Oklahoma and because of their being migrants, which implies for people in California that Okies want to take jobs from them. This is very well expressed when Tom Joad asserts: "'Look, this ain't no lan' of milk an' honey like the preachers say. They's a mean thing here. The folks here is scared of us people comin' west; an' so they got cops out tryin' to scare us back'" (Steinbeck, 2000, 262). With this situation, it seems clear enough that God, the one who helped the Israelites throughout their journey, is not going to give any aid to them in their efforts to create a new Promised Land. God has not given them a place full of manna, of milk and honey, since they are starving. The only solution left for the immigrant families is to become the "new gods", the new people who have to build something better than what they have now. They are alone and God is not going to provide them with food and shelter. Railton argues that the American Dream, which lies on the individuality of the human being and his efforts and courage to start a new life, has betrayed these people and their salvation lies on collective help and joint efforts (Railton, 1990, 33-36). The Joads do not have either manna or money, so they have to stay together and become the new gods who are going to build a new place where living conditions are better and where people are guided by tolerance and love, and not by avarice, rejection and hatred.

\section{The final flood: curse or blessing?}

Finally, I would like to finish this analysis by referring to the final flood that devastates the place where the Joads are living at the end of the book, the camp of boxcars. This final flood stands as a clear opposition to the Flood in the Bible, and it is a symbol of hope and regeneration. In some critical works, this flood is compared to the Flood and Noah in the Bible. The story reads that God was weary of human perversion and sin, so He

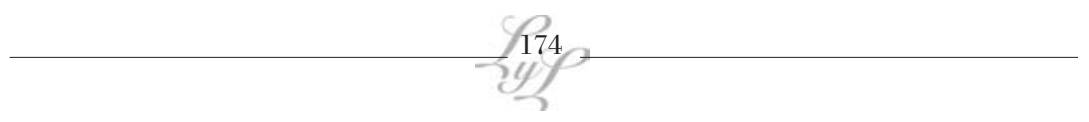


decided to send a great flood to devastate the whole planet. However, he wanted Noah, the only pure man on earth, and his family to be saved. Thus, He warned him of the flood so that Noah and his family could be saved thanks to the construction of the Ark. For forty days with their nights, all the planet was covered with water, every single signal of life disappeared and hope was lost. For some critics, this story is similar to the one that appears in The Grapes of Wrath, since the Joads are caught in their boxcar by a tremendous storm that inundates and destroys the camp where they are living. As Bluestone argues, "the defeated promise of a new land is bitterly dramatized in the last scene. When the land goes, everything goes, too; and the water is the emblem of destruction" (Bluestone, 1972, 109). Similar to the biblical scene, every single piece of land is covered with water and the promises of a better future for the immigrants in California are broken. Nevertheless, I believe that this is not the situation which is represented in the book. What can be found here is not the story of Noah and the Flood, but rather a crystal-clear inversion of it. One of the critics who defend this idea is Rombold, when she states that, "Like Noah, the Joads go through most of the flood in an ark-like structure, the boxcar. But, unlike Noah's family, their ark cannot save them from the waters" (Rombold, 1987, 160). This is true, since Noah and his family were the only human beings that survived in the Flood, whereas in the novel the Joads go through the inundation without any help or ark to save them. Besides, in the Bible, the Flood was a symbol of the wrath of God, it was a kind of punishment for the sins committed by men. After the Flood, hope was lost. In the case of the flood in the book, it is not God's punishment. For the first time in the whole narration, this destruction of the land is not a curse, but a blessing, since "the flood waters recede and leave behind new life" (Rombold, 1987, 160). Life goes on after the storm and humanity is not destroyed by it. It is as if the water was necessary to eliminate and erase all immigrants' suffering and grievances in California, not to erase sin. The flood is a symbol of hope and revival, it points to a new beginning, it symbolises the regeneration of the land. This final rain is a reminder of T.S. Eliot's The Waste Land (1922) and the passage in which the people are wandering in the desert looking for water. Water is presented in this poem as a symbol of regeneration of the earth and a new rebirth from that empty and senseless world in which they are living, a world stripped of faith and liberty. In part 5, "What the Thunder Said", Eliot presents this hope through the arrival of water: "In a flash of lightning. Then a damp gust bringing rain" (Eliot, 2006, line 274). In The Grapes of Wrath this final flood also brings hope to the people. Besides, this end is radically 
opposed to the beginning of the book, when there is a terrible drought that makes people move on to a new place where they can grow crops. This opposition between the beginning and the end of the book has a symbolic meaning, too. The appearance of water at the end implies the resurgence of a new life; it can be seen as a new awakening. It is true, referring to the previously mentioned Noah's story, that the flood is described as a terrible and disastrous one, as can be seen in chapter 29: "The rain began with gusty showers, pauses and downpours. For two days the earth drank the rain, until the earth was full" (Steinbeck, 2000, 452). Nevertheless, as Rombold $(1987,160)$ asserts, the migrants are able to recognize the end of suffering and hardship when they discover new life and hope represented by small blades of grass emerging from the soaked earth: "Tiny bits of grass came through the earth, and in a few days the hills were pale green with the beginning year" (Steinbeck, $2000,454-55)$. This presence of the grass makes it clear that the flood does not mean the end of everything. As long as people are together and struggle for their rights, there will be hope. In this case, this hope is embodied in the bits of grass which appear in the earth, symbolising a new rebirth after so much suffering.

\section{Conclusion: a new book for the people}

Throughout these pages, I have tried to demonstrate that Steinbeck's novel The Grapes of Wrath is a work permeated by biblical symbols, but that they are clearly opposed to the ones that appear in the Bible and are used with a completely different meaning. In particular, it has been my concern to analyse some of the characters that appear in the novel, the journey they take as opposed to the journey of the Israelites in the Bible, and the final flood in the book as compared to the Flood and Noah.

The study shows that the symbols used in this novel are a clear inversion of the ones the Bible uses and that they contribute to the creation of a new type of "bible" which is not religious anymore. Rather, it is a book for the people where all the grievances American people went through in the 1930s are reflected and analysed through the experiences of one single family. It is clear enough that the members of the Joad family, es-

pecially Tom, Ma Joad and Rose of Sharon, are guided by their love for humanity and social justice. The faith that forces them to act as they do is not religious faith, but the belief that things can change if people stand together and work as a great family. In the Bible, God appears as the pillar and saviour who guides humanity through the darkness of the world. In

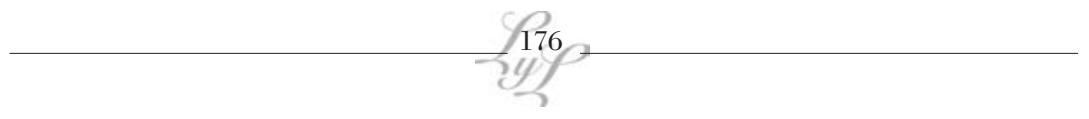


the case of The Grapes of Wrath, people act like gods who serve as guides for one another, while fighting for survival. This book serves as a kind of manual of behaviour where the basics of human ethics and values lie. It is the new book for the people, where the motto is "United we stand," as Ma Joad says. Some critics, as shown previously, agree in comparing this book to the Bible and the stories which are told there. I rather believe that this is a completely different book. Throughout its pages, the reader is able to discover how people behave when they are in great need. Some values and good attitudes such as love, help, social justice and tolerance are shown here. The Joad family represents the situation of many families during the Dust Bowl and the book helps the audience understand their suffering and grievance better. These are circumstances which might have otherwise only been known through history books. The novel thus presents facts in a clearly objective way. In fact, this story is presented as real and the reader puts himself in the Joads' place in a better way and thus understands perfectly the whole situation. Steinbeck's novel is both a guide for the people and a witness to the critical situation of Southern and Midwestern farmers during the Great Depression.

In a nutshell, it is expected that this paper might shed some light upon the meaning of the symbols used in The Grapes of Wrath and upon Steinbeck's real intention behind them. It remains a question for future study to analyse some other characteristics present in this book that have not been considered in the paper. There is hope that further analysis on the topic may contribute to a clearer reading of the novel as a new bible for the people who fight against social injustice and who are in search for a new and better life.

\section{Works Cited}

Bluestone, George, "The Grapes of Wrath." Robert Murray Davis, ed. Steinbeck. A Collection of Critical Essays (1972). Englewood Cliffs, N.J., Prentice-Hall, Inc, 102-21.

Carlson, Eric W., "Symbolism in 'The Grapes of Wrath'." College English 19 (1958), 4, 172-75. Accessed 13 Oct. 2010. <http:// www.jstor.org/stable/371677>.

Chametzky, Jules, "The Ambivalent Endings of 'The Grapes of Wrath'." Modern Fiction Studies 11 (1965), 1, 34-44. Accessed 11 Oct. 2010. <http://pao.chadwyck.co.uk/articles/results. do?QueryType=articles $>$. 
Crockett, H. Kelly, "The Bible and 'The Grapes of Wrath'." College English 24 (1962), 3, 193-99. Accessed 13 Oct. 2010. <http:// www.jstor.org/stable/373284>.

Cruz, Frank Eugene, "In Between a Past and Future Town': Home, the Unhomely and The Grapes of Wrath." Steinbeck Review 4 (2007), 2, 52-75. Accessed 9 March 2012.

Dunbar, Kenton, "Narrative Techniques in Steinbeck's The Grapes of Wrath and Dos Passos' The Big Money." Literatura y Lingüística 14 (2003). Accessed 9 March 2012. <http://www.scielo.cl>.

Eliot, T.S., (2006). La Tierra Baldía, Madrid: Cátedra. Ed. Viorica Patea.

Lisca, Peter, "The Grapes of Wrath." Robert Murray Davis, ed. Steinbeck. A Collection of Critical Essays (1972). Englewood Cliffs, N.J.: Prentice-Hall, Inc, 75-101.

,"The Grapes of Wrath as Fiction." PMLA 72 (1957), 1, 296-309. Accessed 13 Oct. 2010. <http://www.jstor.org/ stable/460231>.

Marshall, Richard D., (2009). The Grapes of Wrath: John Steinbeck's Cognitive Landscape as Commentary on 1930s Industrialization, ProQuest LLC.

Motley, Warren, "From Patriarchy to Matriarchy: Ma Joad's Role in The Grapes of Wrath." American Literature 54 (1982), 3, 397-412. Accessed 9 March 2012. <http://www. jstor.org $>$.

Quint, Harriet, "El amor en 'Las Uvas de la Ira' de John Steinbeck." Espéculo. Revista de Estudios Literarios (2003). Accessed 16 Nov. 2010. <http://www.ucm.es/info/especulo/numero25/ steinbe.html>.

Railton, Stephen, "Pilgrims' Politics: Steinbeck's Art of Conversion." David Wyatt, ed. New Essays on The Grapes of Wrath (1990). Cambridge, Cambridge UP, 27-46.

Rombold, Tamara, "Biblical Inversion in 'The Grapes of Wrath'." College Literature 14 (1987), 2, 146-66. Accessed 11 Oct. 2010. <http://pao.chadwyck.co.uk/articles/results. do? QueryType $=$ articles $>$.

Shockley, Martin, "Christian Symbolism in 'The Grapes of Wrath'." College English 18 (1956), 2, 87-90. Accessed 13 Oct. 2010. $<$ http://www.jstor.org/stable/372506>.

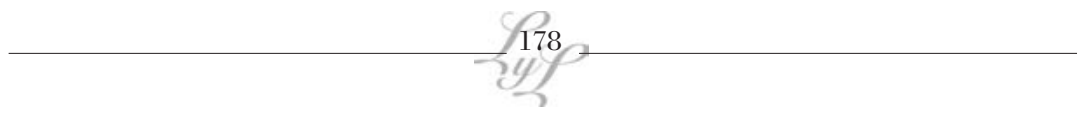


Staples Shockley, Martin, "The Reception of The Grapes of Wrath in Oklahoma." American Literature 15 (1944), 4, 351361. Accessed 9 March 2012. <http://www.jstor.org/ stable/2920761>.

Steinbeck, John, (2000). The Grapes of Wrath, Harmondsworth, Gt. Brit.: Penguin Classics. 